\title{
Recrystallization within Warm-Water Drift Deposits and Cool-Water Carbonate Ramps: Clumped and Sulfur Isotopes from ODP Leg 182 and IODP Leg 359
}

\author{
EVAN W MOORE ${ }^{1}$ AND PETER SWART ${ }^{2}$
}

\author{
${ }^{1}$ University of Miami (RSMAS) \\ ${ }^{2}$ University of Miami \\ Presenting Author: evan.moore@rsmas.miami.edu
}

This study documents diagenetic changes in carbonate sediments deposited in the Kardiva Channel of The Maldives and Great Australian Bight of Australia using $\Delta_{47}$ and $\delta^{34} \mathrm{~S}$ values of the carbonates. These distinct regions are characterized by wide separation in latitude and climate, with the Inner Sea of The Maldives reaching a maximum depth of $550 \mathrm{~m}$, containing warm, relatively shallow, tropical waters, whereas the Great Australian Bight (GAB) possesses much cooler water, with sites gradually sloping down-ramp from 200 to $500 \mathrm{~m}$ water depth. Depositional systems also differ greatly, with sediments of The Maldives frequently deriving from currents that release pelagic and eroded atoll material as current velocity slows due to the interference of the flow with underlying bathymetry, while the GAB sediments are composed of cold-water carbonates formed mainly on the adjacent shelf and deposited on the slope. The warm surface waters of The Maldives, coupled with cooler bottom water, provide a unique location in which clumped isotope recrystallization temperatures may be addressed, and this setting contrasts greatly with the cool-water carbonate-ramp derived sediments of GAB. The $\Delta_{47}$ values from The Maldives cores correspond with temperatures between 15 and $40^{\circ} \mathrm{C}$, with regions of dolomitization exhibiting $5-10^{\circ} \mathrm{C}$ higher temperatures than expected, and $\delta^{34} \mathrm{~S}_{\mathrm{CAS}}$ values $8 \%$ more positive than corresponding seawater. This is consistent with previous observation of dolomite formation under the influence of bacterial sulfate reduction (BSR) [1]. In contrast, GAB cores exhibit cooler clumped isotope derived temperatures $\left(5^{\circ} \mathrm{C}\right.$ near the sediment interface, increasing up to $20^{\circ}$ with depth). The $\delta^{34} \mathrm{~S}_{\mathrm{CAS}}$ values fluctuate from 11 to $25 \%$, showing this systematic has been heavily influenced by pulses of sulfide oxidation and BSR throughout recrystallization of the sediments. At this location the sediments were influenced by differing diagenetic conditions associated with varying hydrologic regimes related to glacio-eustatic sea level changes. This work underscores the importance of understanding the diagenetic influence of recrystallization on temperature and isotopic records.

[1] Murray, S. T., Higgins, J. A., Holmden, C., Lu, C., \& Swart, P. K. (2021). Geochemical fingerprints of dolomitization in Bahamian carbonates: Evidence from sulphur, calcium, magnesium and clumped isotopes. Sedimentology, 68(1), 1-29. 